\title{
International Conference on Neoproterozoic Sedimentary Basins, Neoproterozoic Subcommission Workshop on Ediacaran Paleobiology, and IGCP Field Excursion to the East Sayan Mountain Range
}

\author{
30 July - 14 August 2011, Novosibirsk, Russia
}

Numerous Neoproterozoic sedimentary basins were developed on the Siberian Craton, and the Siberian successions play an important role in the Neoproterozoic biostratigraphy, chemostratigraphy, basin dynamics, and petroleum exploration. To take advantage of Siberia's rich geological and paleobiological heritages, Russian geologists at the Trofimuk Institute of Petroleum Geology and Geophysics in Novosibirsk organized an international conference on Neoproterozoic sedimentary basins and a workshop on Ediacaran paleobiology (Novosibirsk, 30 July - 1 August, 2011), followed by a field excursion to the East Sayan Mountains (2 - 14 August, 2011). These events were sponsored by Russian Foundation for Basic Research, Trofimuk Institute of Petroleum Geology and Geophysics, Russian Academy of Sciences, ICS Subcommission on Neoproterozoic Stratigraphy, and two IGCP projects [IGCP 512 "Neoproterozoic Ice Ages" led by G. Shields and Emmanuelle Arnaud, and IGCP 587 "Of Identity, Facies and Time: The Ediacaran (Vendian) Puzzle" led by Patricia Vickers-Rich, Mikhail A. Fedonkin, James G. Gehling, and Guy M. Narbonne]. The main goal of the combined conference, workshop, and field excursion was to encourage interdisciplinary investigations of Neoproterozoic Earth history through international collaborations.

The conference was inaugurated by a keynote address on the petroleum potential of Neoproterozoic basins in eastern Siberia by Aleksei Kontorovich, who summarized results from decades of petroleum exploration in eastern Siberia. Kontorovich's seminar was followed by four more keynote addresses: Nikolai Chumakov provided a synthesis on Neoproterozoic ice ages, Jay Kaufman discussed the use of chemostratigraphic data

for Neoproterozoic stratigraphic correlation and paleoenvironmental studies, Shuhai Xiao offered insights into the Ediacaran evolution through multiple taphonomic windows preserved in the Doushantuo Formation, and Patricia Vickers-Rich reported new discoveries in Ediacaran paleontology from Namibia. The rest of the conference was

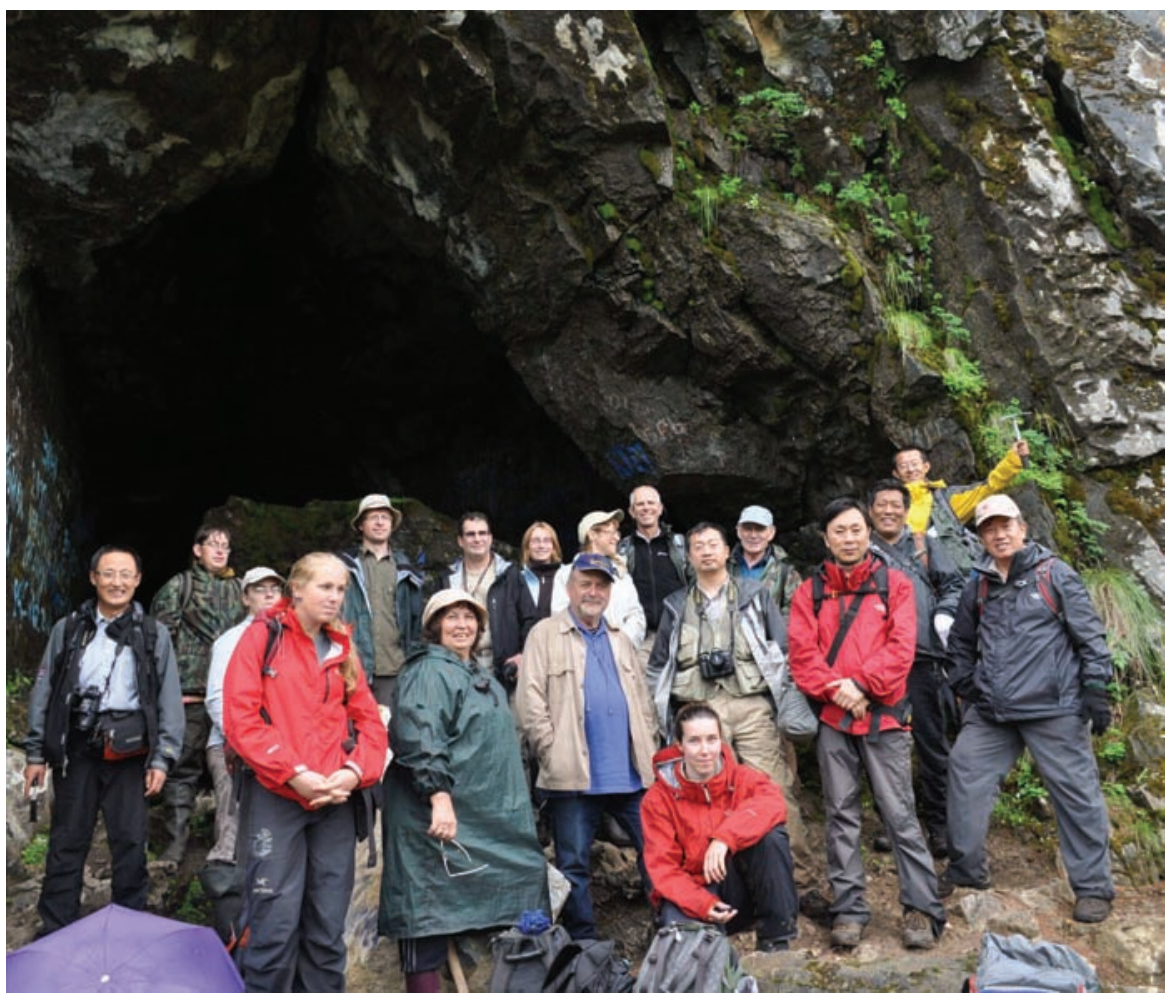

Group photograph of participants in the eastern Sayan field excursion in front of the Pescherny Limestone of the Uda Formation. (Photo: L. Solovetskaya). 
broken into six sessions that covered a wide range of topics including Neoproterozoic biostratigraphy, chemostratigraphy, paleoenvironments, basin analysis, geodynamics, paleogeography, petroleum geology, as well as new paleontological advancements from Siberian Proterozoic successions. A number of presentations/ abstracts (Boris S. Sokolov, Nikolai M. Chumakov, Yulii K. Sovetov, Boris B. Kochnev) also touched upon the important issue of Ediacaran-Vendian correlation. The Vendian System, which is stratigraphically more complete in peripheral zones the Siberian Craton (e.g., the Patom, Baikal and Sayan areas), has many to contribute to the subdivision and global correlation of the Ediacaran System. There were a total of 69 abstracts, which have been compiled in a proceedings volume ("Neoproterozoic sedimentary basins: stratigraphy, geodynamics and petroleum potential. Proceedings of the International conference, edited by D.V. Grazhdankin and V.V. Marusin, Trofimuk Institute of Petroleum Geology and Geophysics, Siberian Branch of the Russian Academy of Sciences, Novosibirsk: IPGG SB RAS, 2011. - 115 p. - ISBN 978-5-4262-0014-2).

The workshop on Ediacaran paleobiology was a follow-up of two previous workshops: the Swedish Workshop on Ediacaran Acritarch Taxonomy (SWEATshop; Uppsala, August 2008) and the Indian Workshop on Acritarchs (Lucknow, February 2010). The Uppsala workshop focused on the taxonomy of some 80 genera and 260 species of Ediacaran acritarchs that have been described in the literature, but unfortunately no Russian materials were available for examination at the Uppsala or Lucknow workshops. Thus, the Novosibirsk workshop offered participants a valuable opportunity to examine the Russian materials, including acritarchs from the Ura Formation in central Siberia, the Vychegda Formation in the Kel'tminskaya region of northern East European Platform, the Lakhanda Group in southeastern Siberia, and the Kamo Group in southwestern Siberia. The materials were kindly provided by Konstantin Nagovitsin (Novosibirsk), Elena Golubkova (St. Petersburg), and Elena Raevskaya (St. Petersburg). Fifteen palaeontologists from Brazil, China, Germany, Russia, and USA participated in the workshop.

Twenty six geologists participated in the field excursion to the eastern Sayan Mountains led by Julius Sovetov. The trip

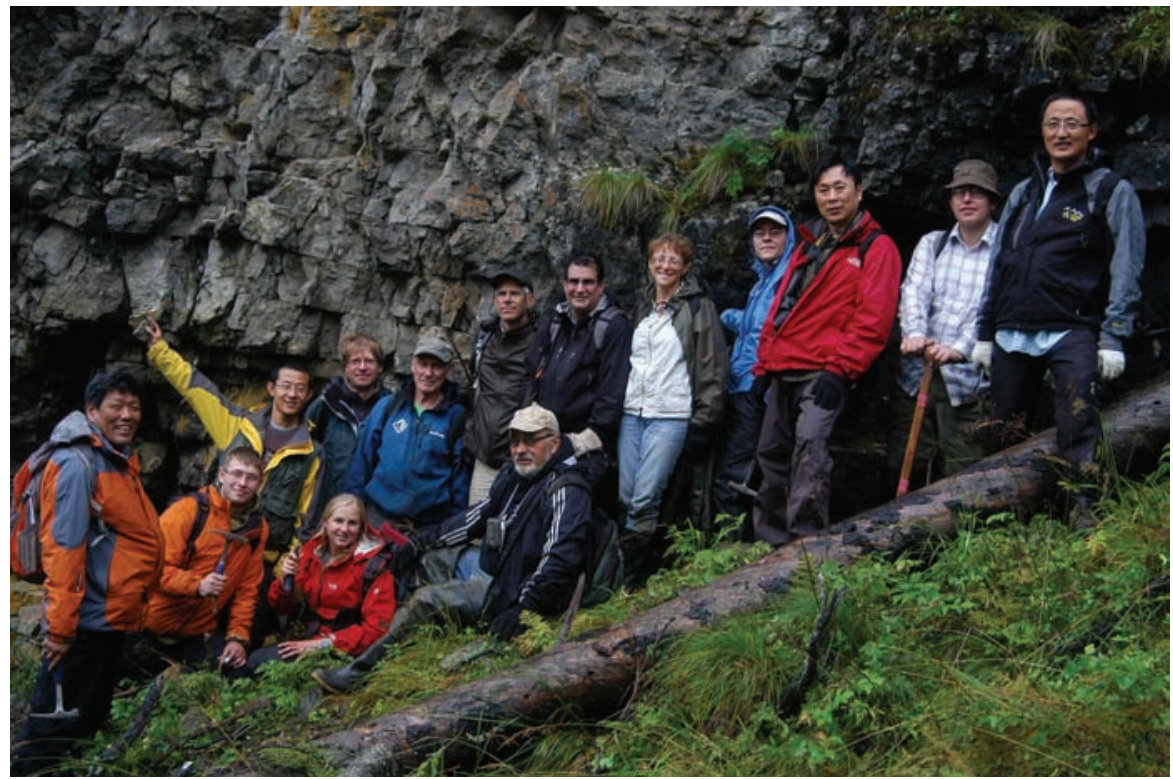

Group photograph of participants in the eastern Sayan field excursion in front of the Ozerki cap carbonate of the Marnya Formation. (Photo: Shuhai Xiao).

started with a 22 hour ride on the TransSiberian train from Novosibirsk to Nizhneudinsk and a 7 hour bus ride to the field camp on the Uda River. Sovetov showed participants Riphean and Vendian rocks that he has been investigating in several decades. In the field area, the upper Riphean Karagassy Group consists of the Shangulezh, Tagul, and Ipsit formations, and the Vendian Oselok Group is divided into, in ascending order, the Marnya, Uda, and Aisa formations. The participants of the Sayan field trip crossed the forested highland terrains on off-road vehicles, boated along the Uda River, and climbed up steep hills to examine Neoproterozoic sedimentary successions in a remote part of the world. A complete guidebook prepared specifically for this excursion (original text by Julius Sovetov, English text by Tatiana Perepelova, photographs by Julius Sovetov and Lyudmila Solovetskaya) provided an overview of the stratigraphy and sedimentology of the Karagassy and Oselok groups and detailed descriptions of the sections.

One objective of the trip was to examine the Karagassy Group (possibly Cryogenian) that consists of $>740 \mathrm{Ma}$ carbonate and siliciclastic rocks deposited on a passive continental margin in dry and hot climatic conditions. Although there are no glacial sediments in the Karagassy Group, impressive paleokarsts at the Tagul (dolostone) - Ipsit (sandstone) boundary implies a significant change in the base level and this is regarded as an important marker for regional correlation.
The Oselok Group does contain beautiful glacial deposits of early Vendian (or late Cryogenian) age, and this was one of the main focuses of the excursion. Three intervals of breccia in the Marnya Formation have been interpreted as glacial in origin, and one of them (the Ulyakha diamictite) contains abundant striated clasts and faceted clasts in a finegrained matrix, as well as polished pavement in the underlying rocks. The Ulyakha glaciation is a potential manifestation of the Marinoan snowball Earth event based on preliminary chemostratigraphic data, although currently there are no geochronometric constraints, other than the stratigraphic relationship with the Riphean Karagassy Group and the early Cambrian Ust-Tagul Formation. A possible ash bed was identified within the Ulyakha diamictite and samples are being analyzed by geochronologists. With luck there will soon be a direct age constraint on the Ulyakha glaciation in southwestern Siberia.

Other trip highlights include the early Vendian transgression facies and putative macrofossils. The transgression deposits in the Bolshaya Aisa Member of the Marnya Formation lie above postglacial continental outwash-plain sandstone or channel-bar quartzite and cap dolomite. This member contains imprints and casts that Sovetov reported as soft-bodied macrofossils.

In the late Ediacaran Period, the Siberian Craton underwent an orogeny that produced thick (up to $1500 \mathrm{~m}$ ) molasse in foredeeps along the southwestern craton margin. The sedimentary fill of the Sayan Foredeep includes channel deposits of the Aisa Formation. The 
excursion participants examined them at the Plity locality where a high-energy braided river system developed at the onset of the foredeep sedimentation. The late Ediacaran orogeny in Siberia, along with the subsequent extension and transgression deposits with trace fossils such as Treptichnus pedum, is another tie for global correlation.

The logistic support for the field excursion was excellent. Boris B. Kochnev, with a team of students (Natalia V. Bykova, Yuriy Y. Goy, Anton V. Kolesnikov, Vasiliy V. Marusin, Vladimir I. Rogov, and Daniel V. Krechetov), helped to run the field excursion smoothly. Lyudmila V. Solovetskaya assisted in a preparatory trip in 2010 and shared with the participants her fabulous field photographs. Tatiana I. Perepelova did an excellent job in translation. Dmitry Vitoshkin and his family offered warm hospitality and a Russian banya at the freezing Karapchatui Homestead, making this excursion truly enjoyable. For those who did not have a chance to participate the conference and field excursion, they are welcome to download (http://web.me. com/f6oeoua/Site/ N eoproterozoic_Sedimentary_Basins.html) or request the conference proceedings and the excursion guide from Dmitry Grazhdankin (dima.grazhdankin@gmail.com).

\section{Shuhai Xiao}

Department of Geosciences, Virginia

Polytechnic and State University,

Blacksburg, Virginia 24061, USA

\section{Dmitriy V. Grazhdankin,}

Julius K. Sovetov

Trofimuk Institute of Petroleum Geology and Geophysics, Siberian Branch of the Russian Academy of Sciences, Koptyug Avenue 3,

Novosibirsk 630090

Russia

\section{Alan J. Kaufman}

Departments of Geology and Earth System Science Interdisciplinary Center,

University of Maryland,

College Park,

Maryland 20742, USA

\section{Patricia Rich}

School of Geosciences, Monash University,

Victoria 3800, Australia 